\title{
Frøslevskrinet - er rejsen nu endt?
}

\author{
af Hans Ole Matthiesen og Jørgen Smidt-Jensen
}

Gennem de sidste 100 år er det diskuteret, hvor og hvornår det berømte Frøslevskrin er fremstillet. Naturvejleder, cand. phil. Hans Ole Matthiesen, Aabenraa og cand. mag. Jørgen Smidt-Jensen, Kulturhistorisk Museum i Randers, har underkastet skrinet en fornyet undersøgelse og kan her sandsynliggøre en endelig løsning på gåden: Skrinet kan være fremstillet på Hildesheim-egnen i begyndelsen af 1000-årene.

\section{Frøslevskrinet - et knopskrin}

120 år er gået siden det lille emaljerede Frøslevskrin i 1872 dukkede op under tørvegravning i Frøslev Mose, for kort derefter at blive smuglet over grænsen fra det preussisk besatte Sønderjylland. Det står i dag på Nationalmuseet i København og er stadigvæk omgardet af en vis mystik, da skrinets alder og oprindelsessted endnu er omdiskuteret og næppe klart sandsynliggjort.

Frøslevskrinet slutter sig til en samlet gruppe af romanske, emaljerede skrin, kaldet knopskrin. Skrinene er alle udført i forgyldte kobberplader med indlagt emalje. De ialt 10 arbejder $^{1}$ er alle forsynet med en række kobberknopper, der er fastgjort $\mathrm{i}$ gennemboringer $\mathrm{i}$ pladernes uemaljerede yderkanter - heraf navnet knopskrin (IIl. 1). Ud over deres udsmykning med knopper er skrinene usædvanlige med hensyn til fremstillingsteknik og farve- og motivvalg. De 10 knopskrin er alle fremstillet på et værksted af høj teknisk kvalitet.

Teknikken er såkaldt champleve (fransk, med betydningen »løftet mark«), også kaldet grubeemalje, hvor de kanter, der senere forgyldes, står op som langstrakte øer $i$ et emaljehav. Værkstedets høje kvalitet giver sig til kende de steder, hvor emaljen er faldet ud: Man ser, at den støbte plade har været meget tæt på det færdige produkt, således at behovet for efterbehandling inden emaljeringen har været minimal.

\section{Et usædvanligt farvevalg}

Skrinenes farvevalg er usædvanligt, set i relation til, hvad vi ellers kender fra romansk tid. På Frøslevskrinet er det hvid, grøn og blå i mange nuancer: lapis lazuli, ultramarin, pariserblå og lyseblå. Hertil guld på alle ikke-emaljerede kobberdele. På de øvrige knopskrin finder vi tillige grøn, gul og rødbrun. Guldbelægningen på kobberet understreger såvel farverne enkeltvis som kombinationen af modfarver.

Skrinenes ikonografi - deres billedsprog - lægger sig ikke op ad, hvad vi 


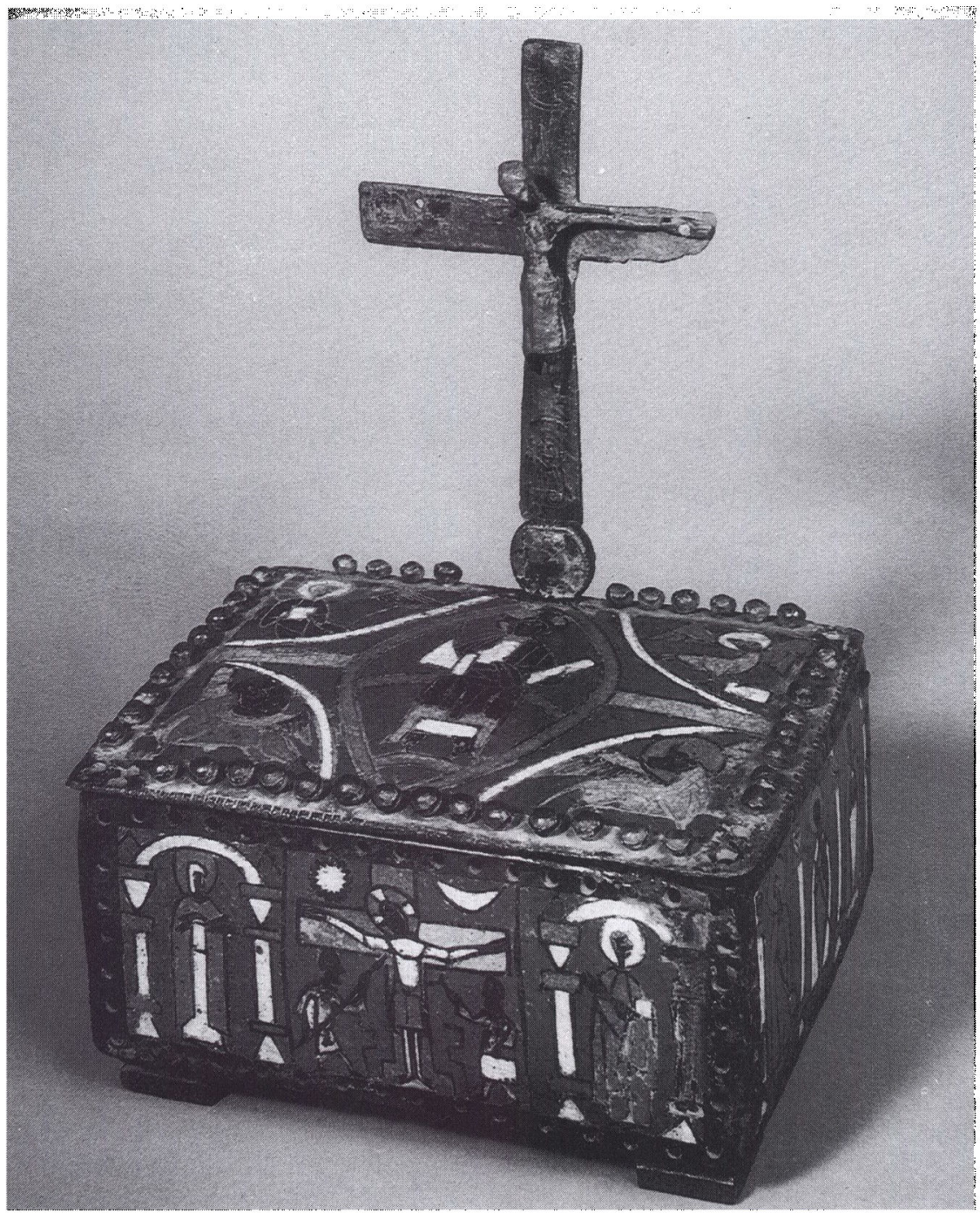

IIl. 1: Froslevskrinet med det tilhorende krucifiks klarede det lange ophold i mosen ganske godt. Til gengald har det knebet mere med at placere det $i$ tid og sted. Foto Helge Krempin.

for eksempel kender fra de helgenskrin, der fra midten af 1100 -tallet produceres i de store værksteder i Köln, Meuse og Limoges. Den knytter sig derimod til den ældre romanske tanke om »ecclesia militans«, hvor Kristi frelsergerning fremhæves.

Frøslevskrinets motivvalg er enkelt (IIl. 1a): På låget findes Kristus i mandor- 

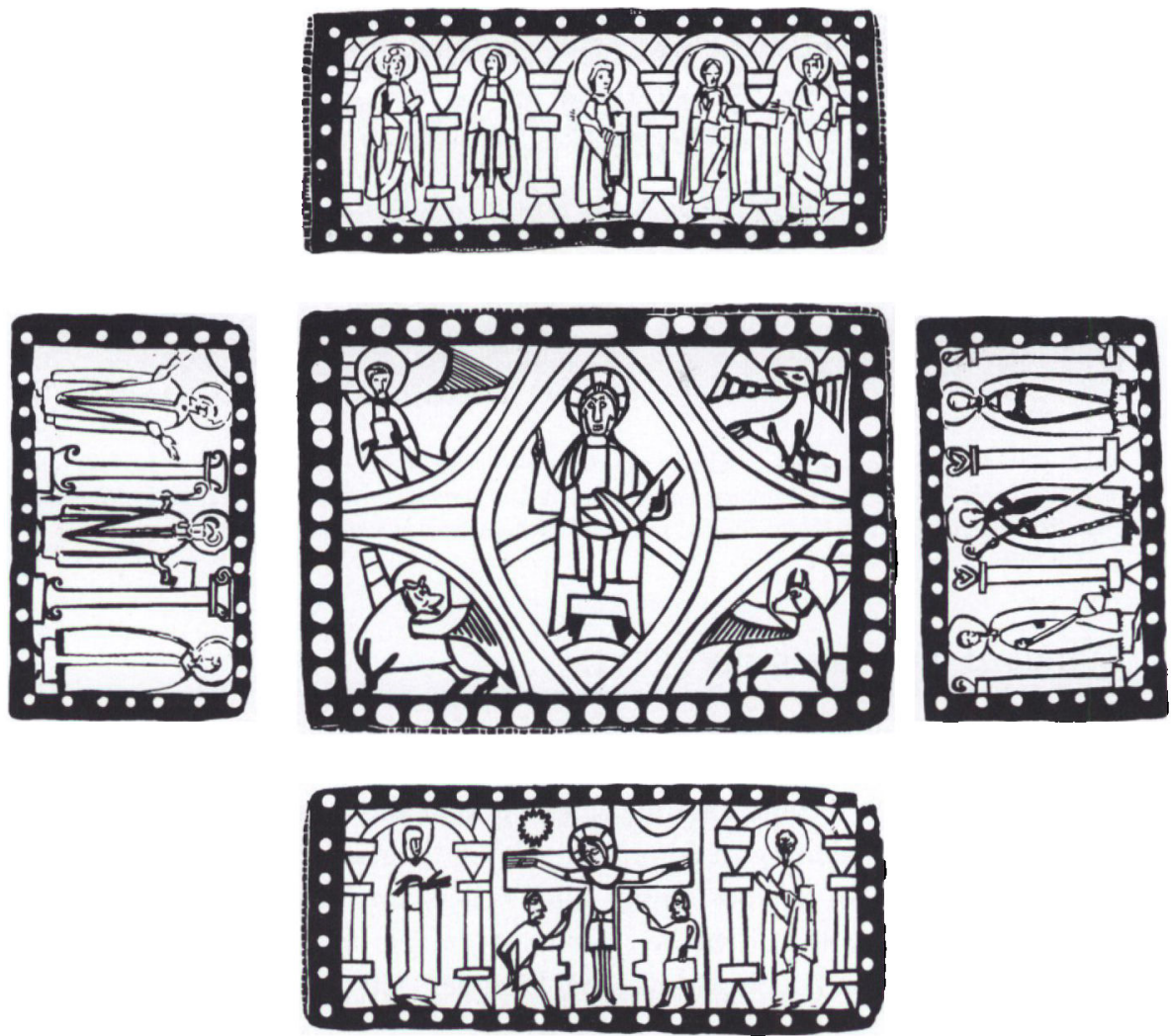

III. Ia: Froslevskrinets motiver. I midten làget, nederst og overst for- og bagside, til hojre og venstre de to gavle. Gengivet efter Poul Svensson: Froslevskrinet (1981).

la omgivet af symboler på de fire evangelister, Mathæusenglen, Johannesørnen, Markusløven og Lukasoksen. Forsiden har i midten en afbildning af korsfæstelsen og de to soldater Stephaton og Longinus, samt jomfru Maria og Johannes Døber. På begge gavle er der tre personer, på bagsiden fem, alle indrammede af søjler. På det tilhørende løse kors den korsfæstede Kristus og indgraverede evangelistsymboler samt Gudslammet. Motiverne på de andre skrin ligger tæt op ad Frøslevskrinets (Ill. 2).

Korsfæstelsen, Kristus i mandorla og forskellige helgener er hyppigst forekommende, evangelisterne og fremstillingen af Kristi Fødsel findes på flere skrin, mens et enkelt bl.a. er udsmykket med de tre vise mænd og flugten fra Ægypten. 


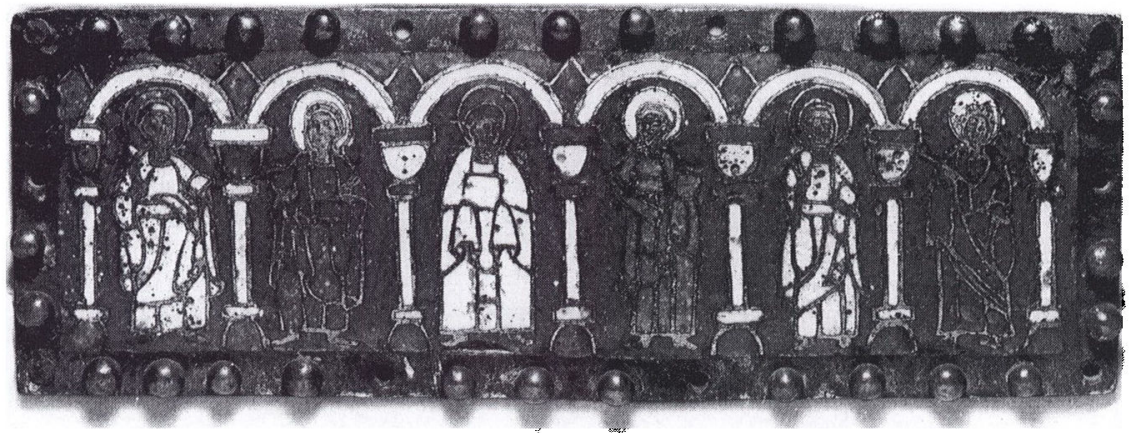

Ill. 2: Romskrinets lose langside er ganske typisk for de øvrige skrin. Her ses seks personer der står under arkadebuer båret af sojler. Mange af personerne kan genfindes fra et skrin til et andet. Gengivet efter P. Svenssons bog om Froslevskrinet, som i enhver henseende rummer de bedste fotografier.

\section{Standard-dateringen må rykkes}

Knopskrinene - og dermed Frøslevskrinet - er hidtil anset for at være 1100tals arbejder med Poul Nørlunds rammedatering 1075-1150 som den mest udbredte datering. ${ }^{2}$ Denne datering sammenholdt med skrinenes specielle karakter har givet anledning til en omfattende og langvarig debat om skrinenes produktionssted. Da de som omtalt intet fællesskab - hverken ikonografisk eller teknisk - har med de værker, der i 1100-tallets midte blev produceret i de store værksteder i Köln, Meuse og Limoges, har man været nødt til at henføre skrinene til ukendte produktionssteder. Man har antaget, at skrinenes ikonografiske "primitivitet " er et udtryk for produktionsstedet og ikke - som denne artikel vil forsøge at belyse - et udtryk for deres alder. Det har således været almindeligt at anse skrinene, der er blevet betegnet som »Der Gipfel der Primitivität ${ }^{3}$ for at være nordtyske eller danske, eventuelt engelsk/irske arbejder.

Netop problemerne med at forene datering og produktionssted må give anledning til overvejelser om holdbarheden af den hidtidige datering. I det følgende vil vi tage dette op til debat, og vi vil med udgangspunkt $i$ knopskrinenes usædvanlige træk forsøge at finde forbilleder for disse specielle metalarbejder og dermed forsøge at anvise nye veje til bestemmelse af skrinenes produktionssted. ${ }^{4}$

\section{Skrinenes datering}

Før Nørlunds datering af knopskrinene til 1075-1150 har de været betragtet som værende fremstillet $\mathrm{i}$ perioden fra slutningen af 12 . århundrede til hen $\mathrm{i}$ 
13.århundrede, men med en enighed om, at de var fremstillet $i$ det primitive Norden. Først i 1980-erne er der sat spørgsmålstegn ved Nørlunds datering, ligesom Norden som produktionssted er draget $i$ tvivl. ${ }^{5}$

Nørlund nærede også en ikke helt ringe tvivl omkring sin egen datering. På en lang række punkter gik han faktisk bag om sin egen datering, når han redegjorde for enkeltelementer i skrinene. Han henviste til, at klædedragten på helgenerne ikke hører til i det 12. århundrede, men har sine nærmeste paralleller i det 9.århundrede. Her henviste han til en tegning fra Trier fra 9.årh.'s begyndelse.

Han nævnte endvidere, at korsfæstelsen på det løse kors stilistisk skal henfores til tiden omkring $1000,{ }^{6}$ og at fødderne på skrinet fra Monte Cassino kan sammenlignes med dem under St. Andreas-bærealteret fra Trier fra $0.975 .^{7}$ Og ret overraskende inddrager han den i kunsthåndværkskredse så kendte Rogers von Helmarshausen fra o. 1100 i gennemgangen af New Yorkskrinets låg, udført $\mathrm{i}$ den såkaldte »Opus interasile«-teknik. ${ }^{8}$ Hele 13 gange går han bagom sin egen datering 1075-1150, og netop i frygten for at gøre tingene for gamle grundlægger han problemerne med at få fundet et produktionssted for Frøslevskrinet og de ni andre skrin.

Nørlund var som omtalt selv klar over svagheden i sin datering af skrinene, og i et memorandum fra 1948 uddyber han dette: »Jeg har i sin tid ... hypotetisk foreslået dem som dansk arbejde fra tiden kort efter 1100. Jeg har imidlertid aldrig fundet, at mine argumenter var særlig stærke. Jeg har nu taget spørgsmålet op igen til overvejelse ... og jeg føler mig herefter endnu mere tvivlende end før. Jeg vil snarest være tilbøjelig til at frafalde den danske hypotese, og formoder, at oprindelseslandet er Nordvest-Tyskland eller eventuelt i England . $^{9}$

Nørlunds største tvivl gik altså stadig på oprindelseslandet på trods af hans egen påvisning af en række elementer, der peger betydeligt længere bagud $i$ tid end hans egen datering. Ydermere burde det, hvis skrinene skulle være fremstillet op mod 1150 som foreslået, være muligt at finde lighedspunkter med værker fra de store værksteder i Limoges, Köln og Meuse. Ser vi på en række af disse arbejder som Eilbertus af Kölns bærealter (1150-60), den hellige Heriberts skrin (Köln 1160-70) eller rejsealteret fra Stavlot (1150-60), er der intet fællesskab med disse værker, hverken teknisk eller ikonografisk. ${ }^{10}$

Skrinene fra denne periode er tydeligt præget af »ecclesia triumfans«, hvor den katolske kirke glorificerer de forskellige medlemmer af den kristne menighed, i et forsøg på at bekræfte den højkatolske systemtænknings iboende værdi. De omtalte skrin er tillige noget større og lavet af ædelmetaller.

På baggrund af de mange tidlige stiltræk, de manglende muligheder for at sammenligne med 1100-tallets metalarbejder og dermed problemerne med 


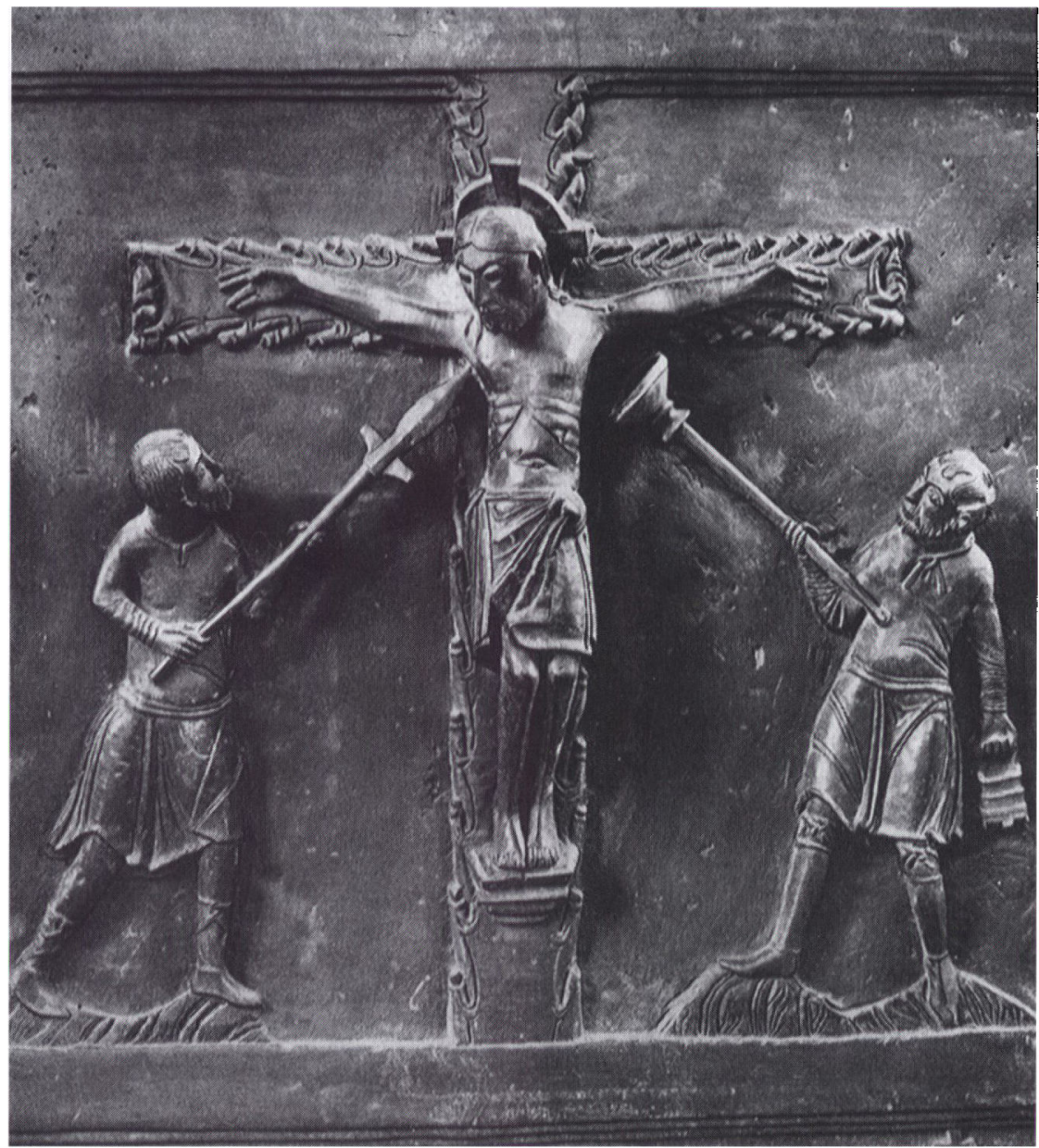

IIl. 3. Korsfastelsesscenen fra doren i St. Mikaelskirken i Hildesheim. Kristus, Longinus og Stephaton. Den stramme symmetri prager $i$ ovrigt hele doren. Gengivet efter Wesenberg.

overhovedet at finde et produktionssted for skrinene, synes det rimeligt at tage skrinenes formsprog og teknik som udtryk for alder og ikke for et bestemt produktionssted.

Med andre ord: Knopskrinene må være aldre end 1075 .

Skrinenes produktionssted

Da skrinene må dateres til tiden før 1075, vil det være relevant at søge forbilleder til disse i områder, hvor der i 1000-tallet fandtes metalværksteder. 


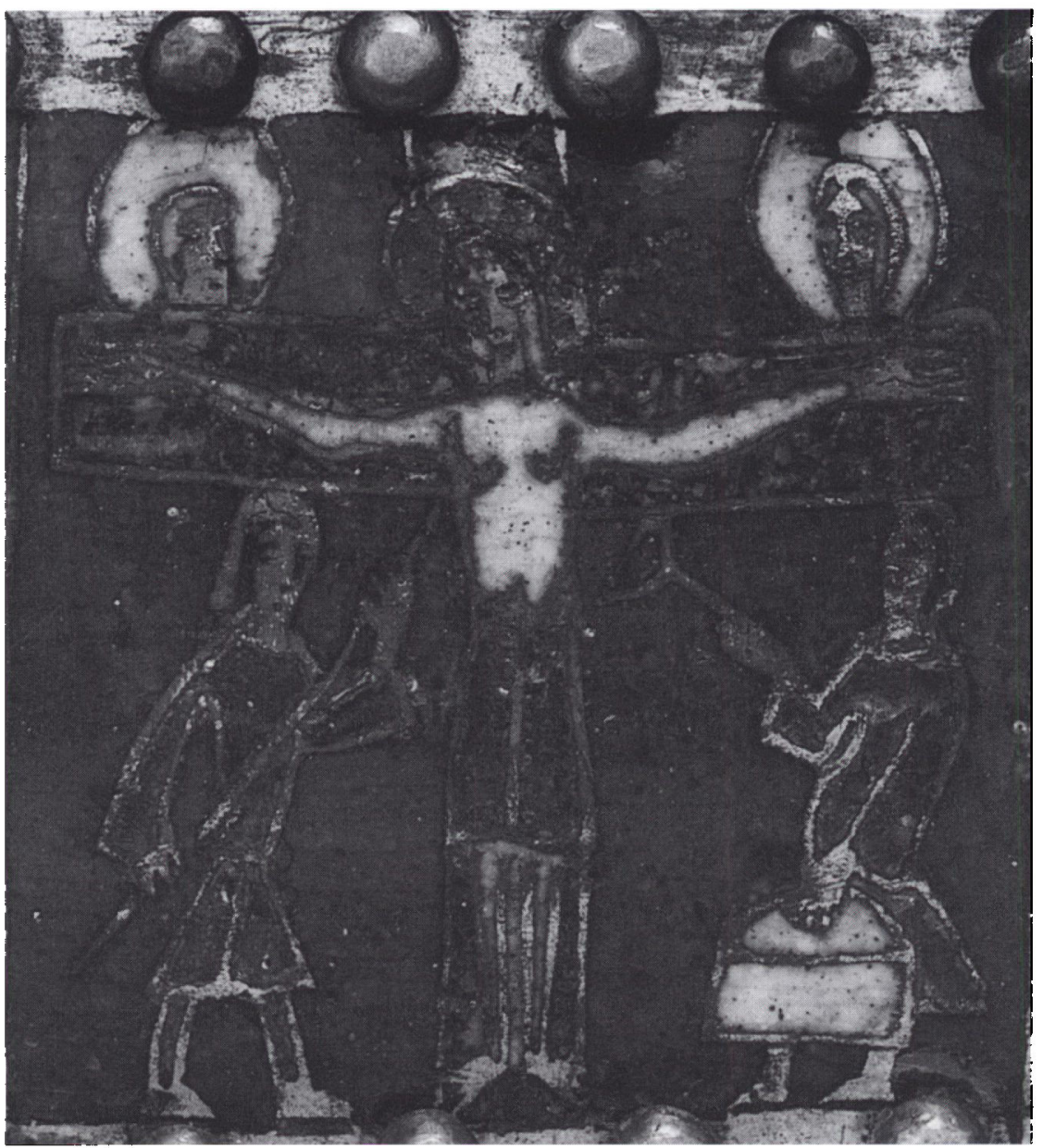

III. 4: Korsfastelsesscenen fra New York-skrinet er en nasten tro kopi af det foregående motiv fra doren, lige fra vildsvinespyddet, over kladedragtens folder til den akavede måde Stephaton giver Kristus en kalk med eddike. Froslevskrinet og Monte Cassinoskrinet har samme symmetri. Gengivet efter Poul Svensson, 1981 .

Vi må derfor se på metalværksteder og håndværkscentre i 1000-årene, sammenligne skrinenes billedsprog med det vi kan finde i 900- og 1000-årenes bogmalerier, samtidig med at vi ser på, hvor det næsten abstrakte farvevalg har været stil og kutyme.

Tre af skrinene befinder sig i Tyskland, tre i Italien, et i Danmark, mens tre, der alle er opkøbt ved auktioner i nyere tid, findes i henholdsvis England og USA. 
Lad os først slå fast, at en dansk metaltradition fra 1000-tallet næppe kan have frembragt disse arbejder. De tidligste metalarbejder må være de gyldne altre, alle fra 1100-tallets midte og frem. ${ }^{11}$ Større emaljearbejder fra 1000-tallet kender vi heller ikke. Spanien har en kort overgang været inde i billedet, idet et skrin fra Rodaklosteret i Nordspanien fejlagtigt blev omtalt som et knopskrin. Det drejer sig imidlertid om et Limogesarbejde. Spanien må herefter være ude af billedet som produktionssted.

Da der findes tre skrin med tilknytning til Italien og tre til Tyskland, er det rimeligt at dreje focus for undersøgelsen mod de to lande.

Vender vi blikket mod Italien, har champleve-emaljen ikke haft gode betingelser her $\mathrm{i}$ tiden før 1075. Det italienske emaljearbejde fra denne periode var i høj grad teknisk inspireret af det byzantinske riges guldsmedekunst. Man arbejdede med den såkaldte celleemalje, hvor den guldtråd, der adskilte de farvede emaljer, blev fastgjort på pladens bund. Det smukke Dagmarkors er et typisk celleemaljearbejde. ${ }^{12}$ De store skoler i 1000-årenes Italien, Romskolen og den Sicilianske skole, producerede således arbejder, der i dag kun vanskeligt kan adskilles fra inspirationen i øst. ${ }^{13}$ Farvevalg som på Frøslevskrinet kendes ikke fra den italienske celleemalje. På den baggrund virker det ikke sandsynligt, at knopskrinene skulle have deres oprindelse i Italien.

Derimod ser det ud til, at der kan være en vis rimelighed $i$ at vende blikket

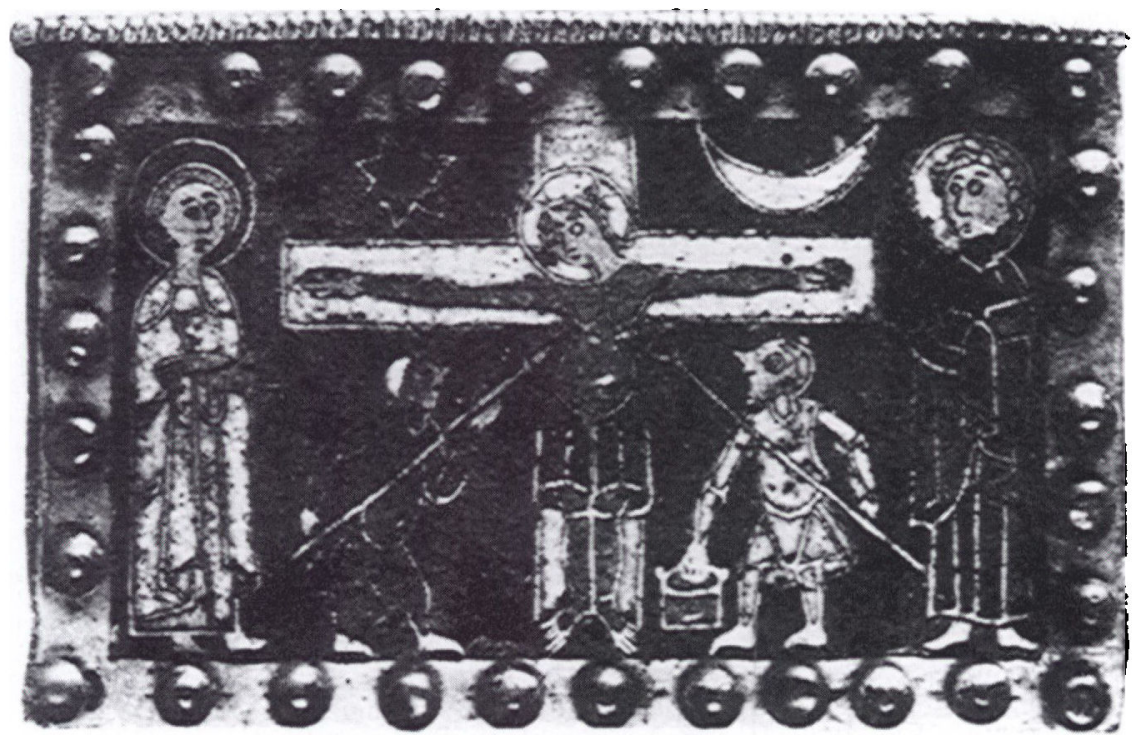

Ill. 5: Detaljerigdommen er udsegt i tre af knopskrinene, således spanden fra Leningradskrinet, der har trak som spanden fra bronzedoren (IIl. 3). Gengivet efter Poul Svensson. 1981. 
mod det tyske område, der jo også er hjemsted for tre skrin. Og det selvom der til dato kun er én, der har turdet anfægte kunsthistorikeren O. von Falkes afvisning i 1904 af det tyske område som skrinenes mulige produktionssted. ${ }^{14}$

\section{Skrinenes farver}

Den stærke anvendelse af farver er karakteristisk for skrinene, og det har givet ét af dem, Welferskrinet, navnet "... det såkaldt stærktfarvede reliquiegemme . $^{15}$

Netop det skrappe farvevalg har været en af hovedårsagerne til tidligere tyske forskeres afvisning af skrinene som produceret i deres eget land.

Men ser vi på miniature- og bogmalerier i det ottonske område, det vi i dag kender som Niedersachsen og Sachsen-Anhalt, er der en udpræget sympati for netop disse virkemidler. I en fremstilling af rigets kejser Otto 3.(983-1002) har sværdbæreren således blåt tøj, blå hat og sko, zinoberrøde gamacher, violet kappe og grønt sværd med guldgreb. I sin bog om ottonsk kunst skriver H. Jantzen: "... dette er et af de mest påfaldende træk ved det ottonske (bog)maleri: Her foretrækker man de hemmelighedsfulde og stemningsskabende farver - langt fra den verdslige verdens farvevalg - på farveskalaens kolde side, farver som violet, lilla, purpur, blå, grøn, både i mættede og tonede nuancer. Harmoniseringen mellem disse vanskeligt sammensættelige farver opnår man enten gennem anvendelsen af guld eller ved loven om modfarver «. ${ }^{16}$ At dette er en beskrivelse af ottonsk bog- og miniaturemaleri skal ikke skjules, men forlæg har det ofte med at være på papir. Umiddelbart kunne man forledes til at tro, at vi her stod med en uvildig persons vurdering af knopskrinenes farvesprog.

Det er således vor opfattelse, at skrinenes særpræg skal ses på baggrund af det ottonske maleris farveholdning, og at produktionsstedet derfor ligger tæt forbundet hermed, et sted i det ottonske rige. Og når man søger et sted, hvor metalhåndværk har givet sig udslag i en eminent støbeteknik, er Hildesheim i 1000-årenes begyndelse ikke til at komme udenom.

Specielt tre værker skal nævnes: De to 4,75 meter høje og 1,15 meter brede bronzedøre fra 0.1015 , støbt $\mathrm{i}$ én arbejdsgang, og oprindelig indsat $\mathrm{i}$ St.Mikaelskirken i Hildesheim. Dertil kommer den 3,79 meter høje Kristussøjle i bronze fra Hildesheim domkirke fra omkring 1020 og lysestagerne sammesteds fra omkring 1000, alt skabt i biskop Bernwards embedsperiode.

Hvis knopskrinene er produceret i dette område i tiden før 1075, må der være forbilleder og ligheder i samtidens værker. I det følgende vil vi forsøge 
Ill. 6: Udtegning af indridsningen på bagsiden af en af pladerne fra Froslevskrinet. Måske har stobemesteren ikke varet ganske tilfreds og hentet inspiration fra forskellige korsfastelsesscener: De kvadratiske endeplader og den langarmede Kristus kunne vare fra Bernwardkrucifikset fra Ringelheim (Ill. 7), Stephaton med eddikekalken fra bronzedoren (Ill. 3). Flere af disse detaljer kan genfindes på skrinet fra Monte Cassino.

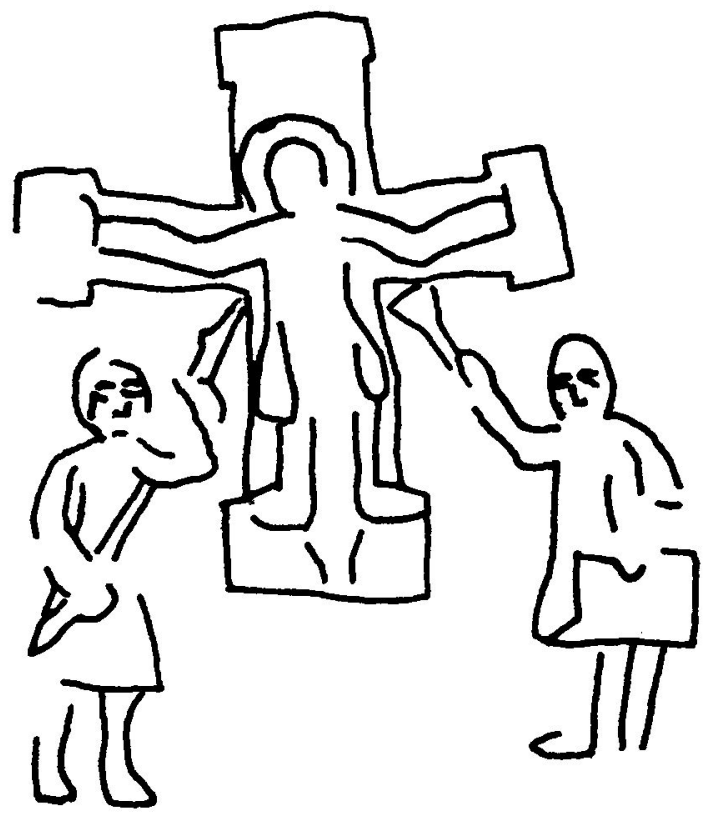

at drage disse sammenligninger for på denne måde at afklare, om skrinene virkelig kan være lavet $\mathrm{i}$ det ottonske område i begyndelsen af 1000-tallet.

\section{Skrinenes motiver}

Valget af motiver samt brugen og udførelsen af disse er for en lang rækkes vedkommende så karakteristisk, at de bør kunne genfindes andre steder i den ottonske kunst fra 900- og 1000-tallet, forudsat at ideen om dette hjemsted er korrekt.

Særlig 6 enkeltelementer ${ }^{17}$ påkalder sig speciel interesse med hensyn til netop valget af motiv, brugen af dette eller den anvendte teknik. Det drejer sig om afbildningen af Stephaton og Longinus og korsfæstelsesscenen, Kristus på det kors der hører til Frøslevskrinet, ornamentikken på New Yorkskrinets og Hildesheimskrinets låg, brugen af søjler og arkader, englenes forkrøblede vinger samt fremstillingerne af Kristi fødsel, De vise Mænd og flugten til Egypten.

Korsfæstelsesscenens afbildning af Stephaton og Longinus er kendetegnet ved den planlagte symmetri med de to stager, der deler fladen mellem korsets arme $\mathrm{i}$ to lige store dele. På sene 900-tals og tidlige 1000-tals gengivelser ses 


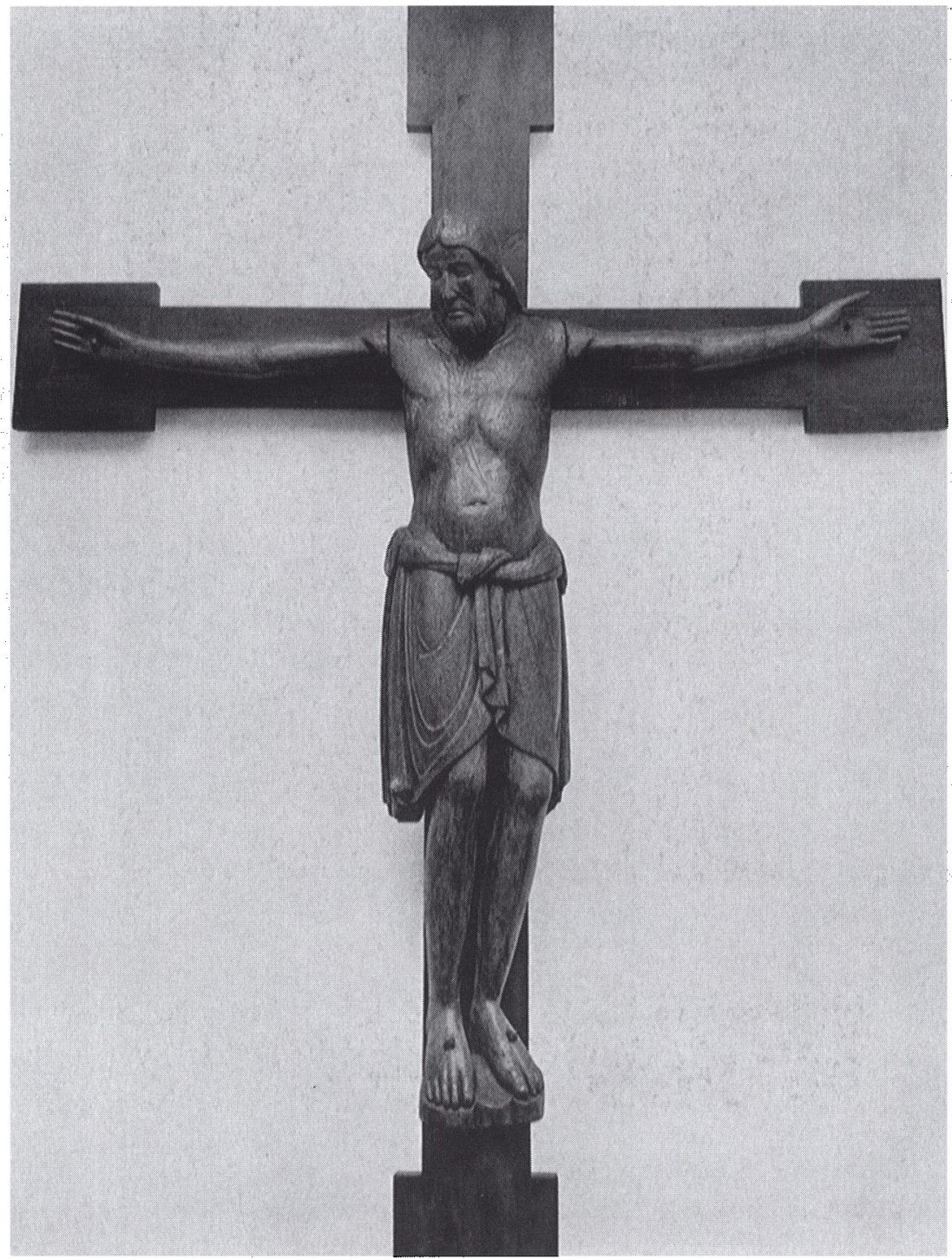

IIl. 7: Bernwardkrucifikset fra Ringelheim er typisk for den ottonske kunsts Kristusfigur: Svavende med tynde lemmer. Kristus på Froslevskrinets krucifiks horer, trods sit medtagne ydre, klart til denne gruppe. Gengivet efter Wesenberg.

spyddet i modsætning hertil ofte at være mere parallelt med korsets længdeakse; nævnes skal blot Adalbero-tavlen fra Metz (i dag i Paris) fra $0.1005 .{ }^{18}$ Det 


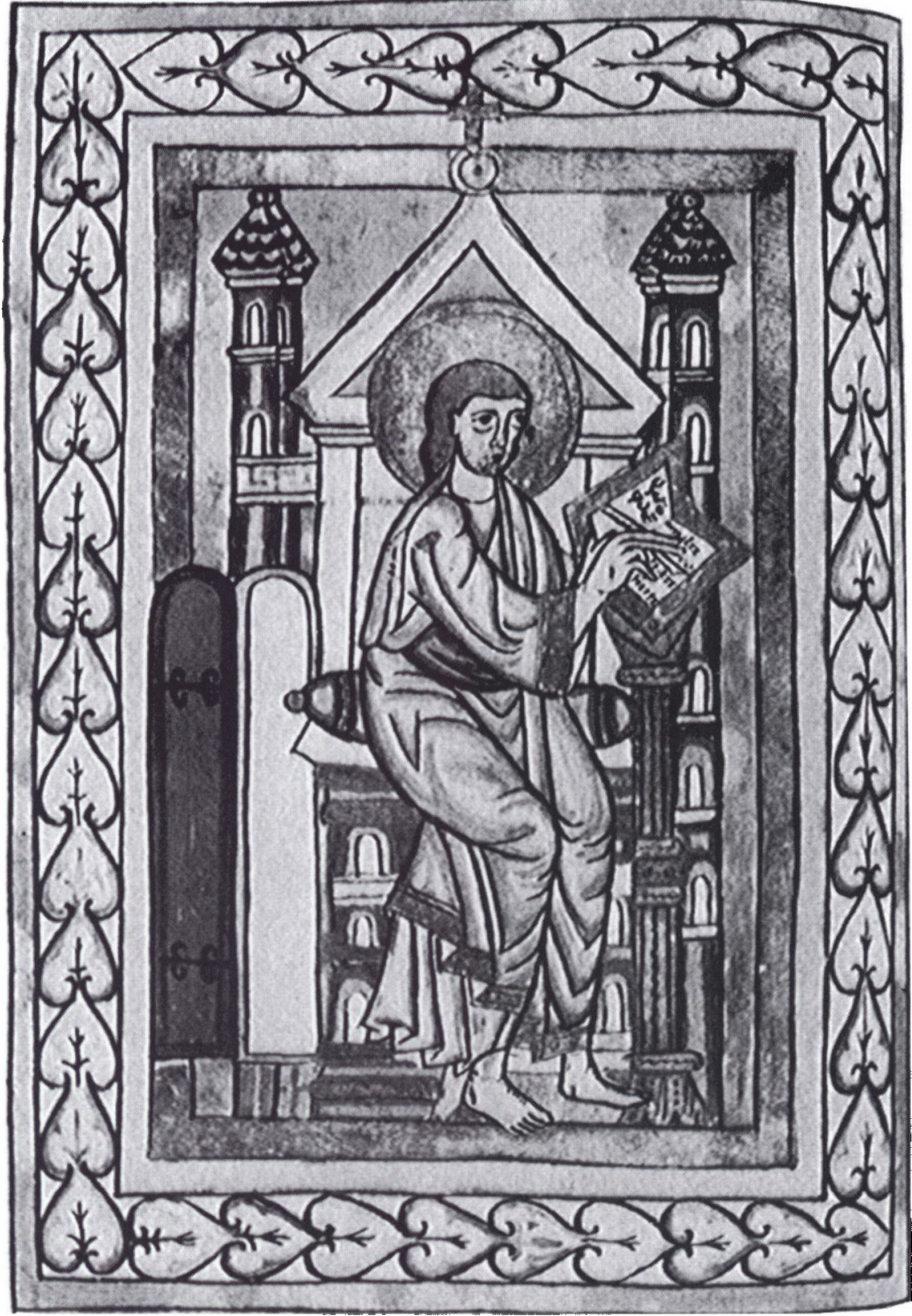

III. 8a-d: Den hjerteformede ranke fra Ilfeldevangeliaret (8a) samt Hildesheim og New York-skrinene. $I$ den tidlige form er den meget primitiv, stiv og lidt slynget, på Hildesheimskrinet (8b) flagrende og på New Yorkskrinet $(8 \mathrm{c})$ ganske stram i sine trak. I varker fra efter midten af 1000 årene ses den $i$ et utal af variationer, således på biskop Hezilos kors $i$ Hildesheim (8d). Gengivet efter Buddensieg s. 109 og forfatterens tegninger. 
Froslevskrinet - er rejsen nu endt?

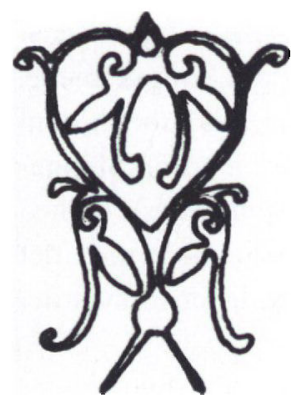

$8 b$
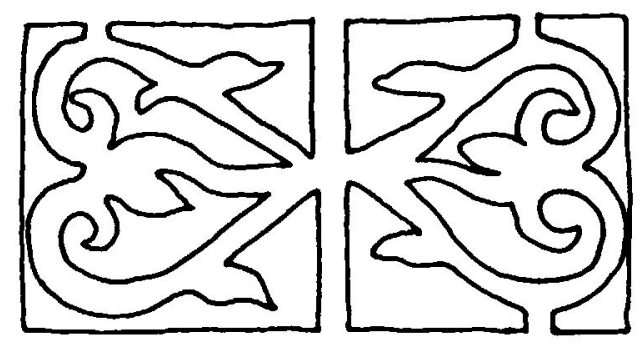

$8 c$

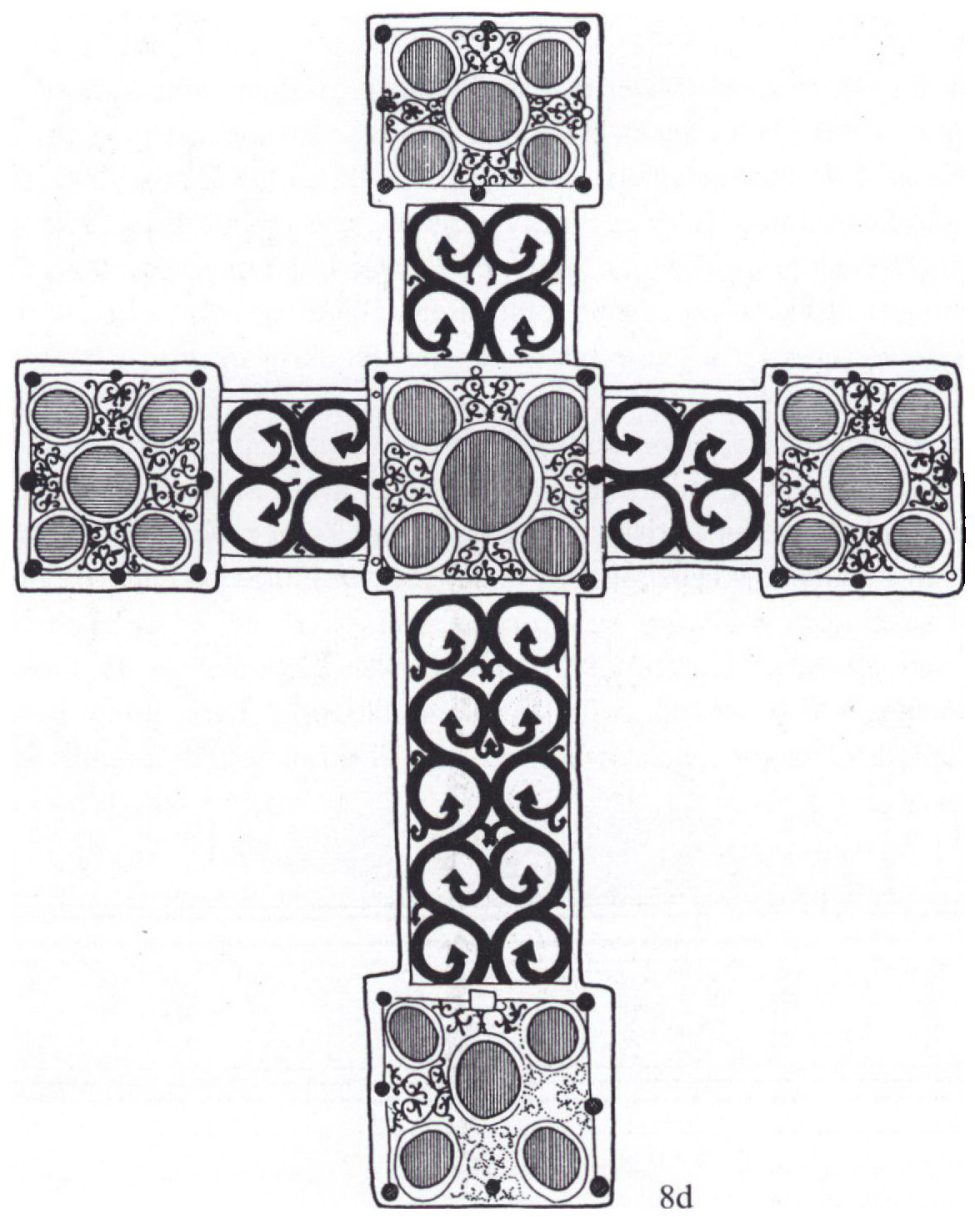


bør derfor være muligt at finde et forlæg, hvor den grafiske udnyttelse af fladeopdelingen har været tilstræbt på en måde, som minder om knopskrinene.

Her må vi pege på bronzedøren fra St. Mikaelskirken i Hildesheim som forbilledet (Ill. 3+4). På denne dørs relief danner Longinus' spyd og Stephatons stage med eddikekalken netop en kompositorisk og symmetrisk helhed ligesom på skrinene. På mindst tre af skrinene er spyddet identisk med det vildsvinespyd Longinus har på bronzedøren, mens denne detalje er forsvundet på de mere dårligt gennemarbejdede skrin.

Stephaton har på flere skrin en underlig akavet holdning, idet han holder stagen med eddikekalken $\mathrm{i}$ højre hånd, samtidig med at han ser ud i billedet. At det netop er en kalk og ikke en svamp, som man ville have forventet på stagen, $\mathrm{og}$ at han holder den med højre hånd, viser en nær forbindelse til bronzedøren. På bronzedøren og på de veludførte skrin er kalken nøjagtig ens.

Den lille eddikespand bliver på de stilmæssigt dårlige skrin til et stort kar, men på de tre fra Hildesheim, Rom og Leningrad ses detaljer, på sidstnævnte anes hankens fastgøring til spandens øskner. (Ill. 5) Også disse træk minder om Hildesheim-døren. Endelig synes Longinus' og Stephatons tøj, ikke mindst den nederste del af kjortlen, at falde i de samme folder som på døren. Denne afbildning er nok ganske central i forståelsen af både det tekniske og ikonografiske i skrinene, og i de nære relationer mellem skrin og dør, i både tid og sted.

Kristusfremstillingen med korsfæstelsen forekommer på 7 skrin og indtager derfor en central rolle hvad angår motivvalg. På alle skrin er korset ganske enkelt og uden detaljer. Kristus har hovedet lidt bøjet mod sin højre skulder, og er kun iført lændeklæde, der er bundet med en knude på livet. På Frøslevskrinet såvel som på Rom- og Monte Cassino-skrinene er de tynde armes knæk ved albuerne markeret klart. Dette træk genfinder vi på Guldbaldsakramentariet fra domkirken i Hildesheim, dat. 1014, hvor det let hældende hoved og kjortelens foldekast svarer ret nøje til skrinene. Tilsvarende ligheder

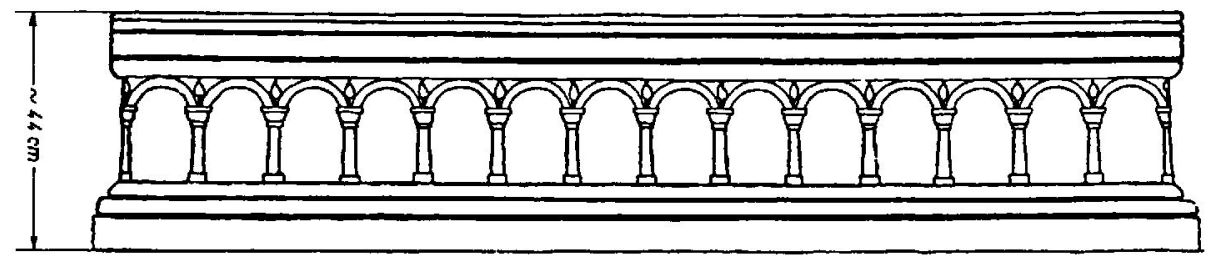

Ill. 9: Sarkofagen der rummer Lothar d. 2, grundlagger af et benediktinerkloster, kan sammenlignes med Romskrinets langside (IIl. 2). Gengivet efter Arenhövel nr. 110. 


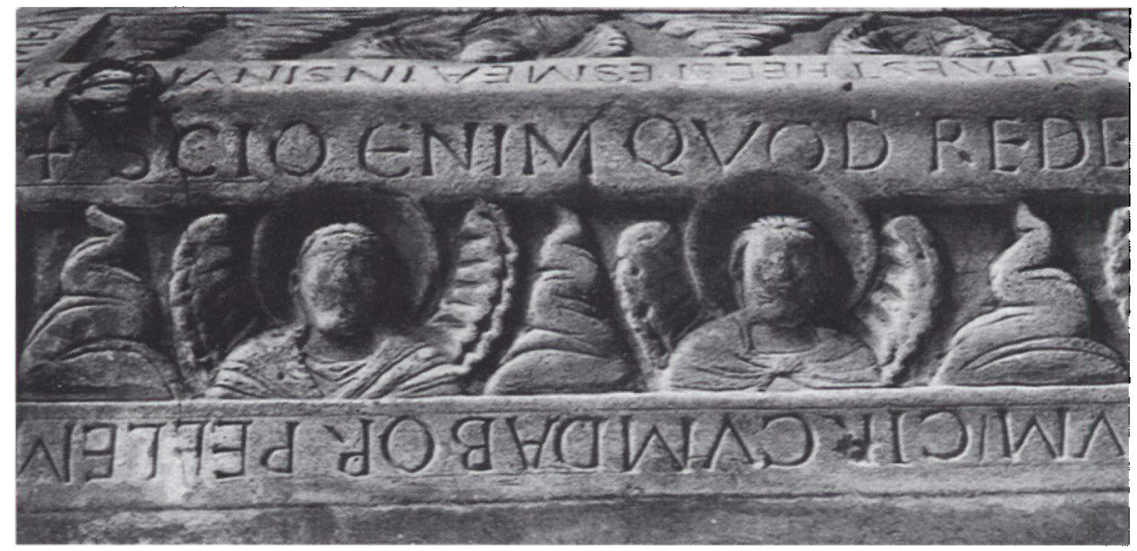

III. 10: Tre skrin har englevinger der ligner birkesfranskbrod, og ligheden i forhold til englevingerne pd biskop Bernwards sarkofag er släende. Gengivet efter Wesenberg.

kan påvises mellem skrinenes Kristusfremstilling og Kristus-figuren på bronzedøren fra St. Mikaelskirken i Hildesheim.

Hvor langt der er fra idé til fardigt vark, fremgår af indridsningen på bagsiden af en af Frøslevskrinets plader. Her er korsfæstelsen og Stephaton og Longinus indridset, og der sker store ændringer i forhold til den endelige udformning på overfladens emaljearbejde: Kristus bliver mindre, Stephaton og Longinus bliver fremstillet fra siden. Korset ændrer sig igen, denne gang uden de 4 brede endestykker. Forbilledet kunne godt være Bernward-krucifikset fra Ringelheim, dat. 1000, ikke mindst fordi suppedanium - det fodstykke Kristus hviler fødderne på - mangler. (Ill. 6) Eller det kunne være Bernwardkrucifikset i sølv, dat 1007/08, omend Kristus dér er en smule mere sammensunken. På bagsiden findes i øvrigt Gudslammet.

Kristus på det krucifiks der hører til Frøslevskrinet indtager en vigtig plads. Den tynde, langarmede Kristus er ganske vist stærk medtaget, men alligevel kan der peges på et par mulige ældre forbilleder fra omkring år 1000. Forlægget kunne således være det ældre Mathildekors, dat. 974-82, samt det yngre Mathildekors, dat. 0.1000 , begge fra Essen. På bagsiden af sidstnævnte findes Gudslammet samt de 4 evangelister indgraveret. Et andet forbillede må være det førnævnte Gundbald-sakramentarie fra Hildesheim, dat. 1014. Indtrykket af den lidt svævende holdning, uden vægt $\mathrm{i}$ armene samt de tynde stive ben er et gennemgående træk for denne gruppe. (Ill. 7)

New Yorkskrinets låg er dekoreret med en rektangulær udsmykning med to graverede og noget usymmetriske hjerteformede bladranker i "opus interasile" 


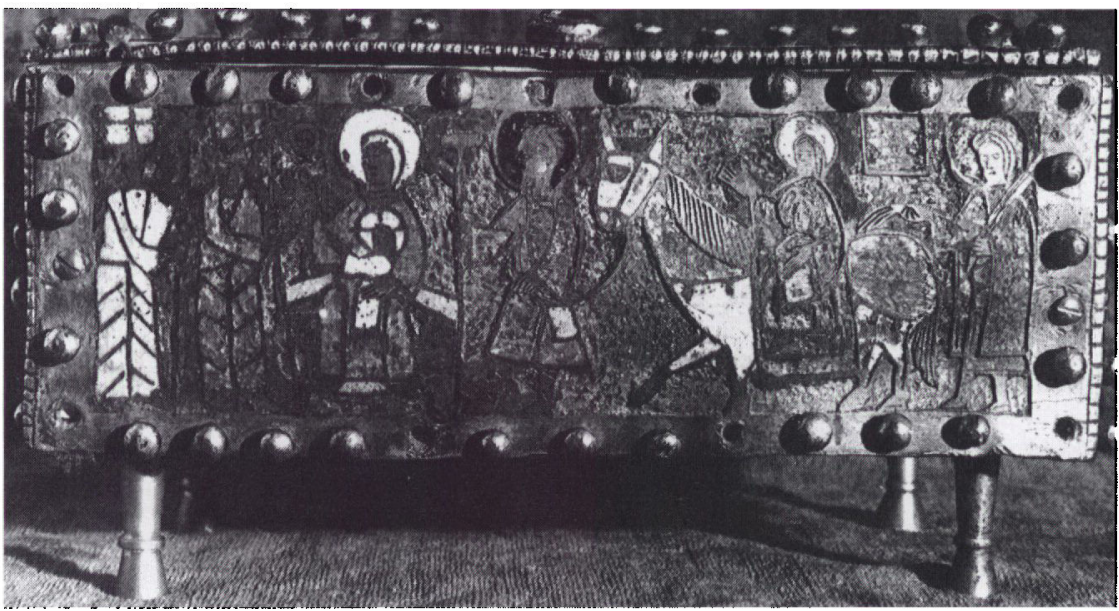

Ill. 11: Fremstillingen af Flugten til Agypten på Monte Cassinoskrinet udviser stor detaljerigdom. Efter Poul Svensson, 1981.

- en graveringsteknik, hvor man skærer overflødigt metal bort, for at opnå en vis dybdevirkning i materialet. Nørlund anfører, at teknikken er svær at datere, men at den er typisk for perioden omkring 1100, udført i værksteder i Sachsen omkring Rogers von Helmarshausen. ${ }^{19}$ (Ill. 8)

Sammenlignelige palmetter i »opus interasile«-agtig teknik er udført i sten på undersiderne af arkadebuerne i Hildesheim St. Mikaelskirken, på overgangen mellem hovedskib og sydlige sideskib.

Disse er opført 1033, andret igen efter en brand i 1046. I øvrigt kendes denne teknik fra klosteret Reichenau ved Bodensøen allerede i det 9. århundrede.

Hildesheimskrinets låg er nok det mest sammensatte af dem alle. Den specielle dyreornamentik og den hjerteformede bladranke er to særprægede motiver. Dyreornamentikken har betydet, at både Irland og England har været bragt på bane som produktionssted.

Derimod kunne inspiration meget vel være kommet fra evangeliaret fra Lindau i Bodensøen. Dette allemanniske arbejde fra slutningen af 8.årh. eller begyndelsen af 9 . årh. er på selve låget til den kasse, der omgiver evangeliaret, udsmykket med seks udgaver med tilsvarende dyreornamentikker.

Den hjerteformede ranke, der både er benyttet på Hildesheim- og Leningradskrinene findes i en endnu ikke helt gennemarbejdet udgave på indramningen til blad 120 i Ilfelder Evangeliaret, dateret til 10.årh. (Ill. 8a), samt på låget til Echternachevangeliaret fra 900 -årenes sidste fjerdedel. Den hjerteformede bladranke er et yndet motiv på metal- og maleriarbejder i Hildesheimområdet, også langt ind i 1200-tallet. 


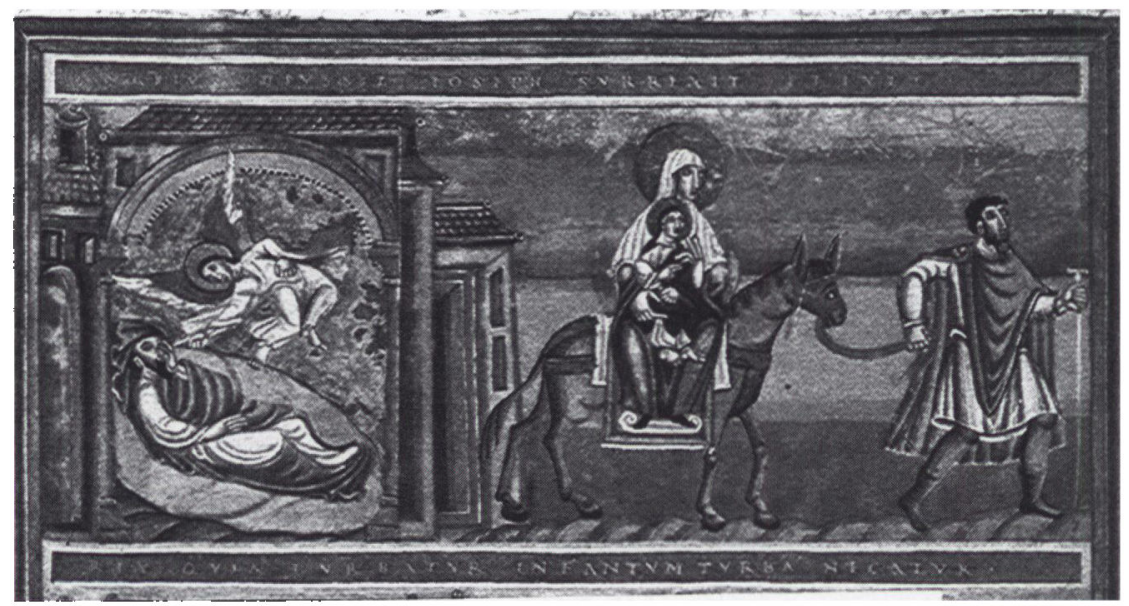

III. 12: Fremstillingen af Fhgten til Agypten pd Monte Cassinoskrinet (III. II) kan nesten uden andringer genfindes pd Echternachcodexen. Gengivet efter Kahsnitz tavle 12.

Den videreudviklede hjerteformede bladranke kan ikke overraskende genfindes på to væsentlige værker fra 1000-tallets Hildesheim, nemlig i en række bånd på den imponerende store, cirkelformede Hezilo-lysekrone i Hildesheim Domkirke, samt på bagsiden af biskop Hezilos kors, begge dateret til 107079. (Ill. 8d)

Et gennemgående træk på alle skrinene er afbildninger af helgener, der står mellem sojler forbundet af arkadebuer. Denne brug af søjler og arkader finder vi også på andet kunsthåndværk fra det ottonske område. En meget imponerende anvendelse af motivet findes på sarkofagen over grev Lothar d. 2, stifteren af benediktinerklosteret i Walbek omkring 950 (IIl. 9). Lothar døde 964, og sarkofagen dateres til århundredets sidste trediedel. Ikke mindst den lille tårnformede spids, der stikker op over arkadebuerne ligger meget tæt op af skrinenes buer.

Ligheder finder vi også til St.Mikaelskirken i Hildesheim, bygget o. 101033. Her har sideskibene 12 arkadebuer, netop det antal helgener, der genfindes på skrinene fra Hildesheim, Rom og Leningrad. I evangeliaret fra Echternach fra o. 1030 ses de 11 disciple imellem søjler med arkader - Judas mangler. De 11 figurer går igen på skrinene fra Frøslev, i Welfersamlingen i Berlin og i New York.

Som noget af det morsomme i skrinenes billeder forekommer »franskbrødsagtigt « udseende vinger hos en del af englene.

Denne måde at tegne englevinger på genfindes på „Kostbarstes Evangeliar" i Hildesheim, dat. 1015, samt på biskop Bernwards sarkofag, skabt efter hans 


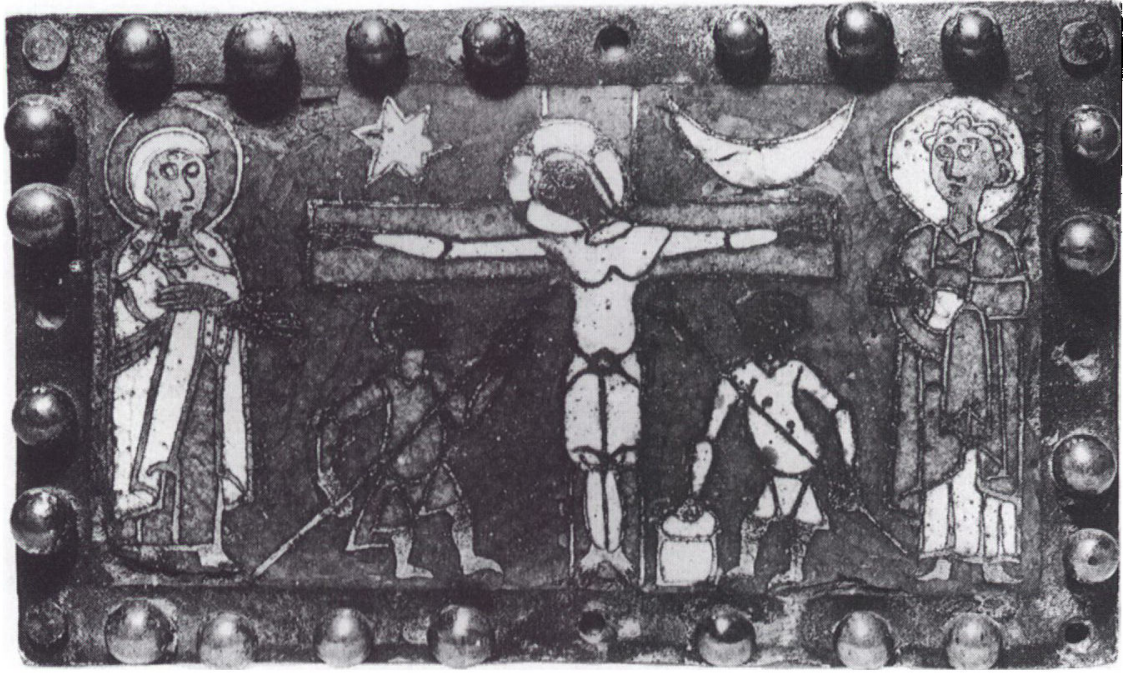

III. 13: Johannes (yderst til hojre) er pa Romskrinet forsynet med 6 store kroller. Gengivet efter Svensson 1981 .

død i 1022. Netop de små streger på den side af vingen, der vender mod ansigtet, er som stjålet fra denne sarkofag (Ill. 10). Også i Goslar-evangeliaret fra ca. 1051 genfindes disse vinger.

Skrinenes billeder fortaller også om Jesu fødsel i stalden, modtagelsen af de vise mand og flugten til Agypten. Fødslen i stalden, som den ses på skrinene fra Monte Cassino og British Museum, ligger tæt op ad gengivelsen på døren fra Hildesheims St. Mikaelskirke, og den genfindes i Echternach Codexen fra. o. 1030. Modtagelsen af de vise mænd genfindes også i Echternach Codex, hvor de vise mænd har samme stav med knop på håndtaget, samme hest der kigger på den nyfødte og samme antydning af Kristus, der peger på de fremmede. Slægtskabet med den gyldne madonna fra Hildesheim Domkirke, dat. 1000, er nærliggende. Endelig skal nævnes flugten til Ægypten på Monte Cassino-skrinet. Her viser Echternach-codexen Josef med samme stav med tværstillet håndtag, hans kjortel viser samme tungeformede stoffald over brystet, Maria sidder tækkeligt sidevendt på hesten, der igen har samme bringe og lårgjorde som i Echternachtavlen fra 1030 (Ill. 11+12).

Et morsomt træk fra Rom-skrinet er fremstillingen af Johannes. Han er fremstillet med gyldne lokker. Mon ikke der har indsneget sig en teknisk fejl, og at forlægget er Johannes fra Gundbaldsakramentariet, dat. 1014 (Ill. 13+ $14)$, hvor glorien er besat med cirkler? 


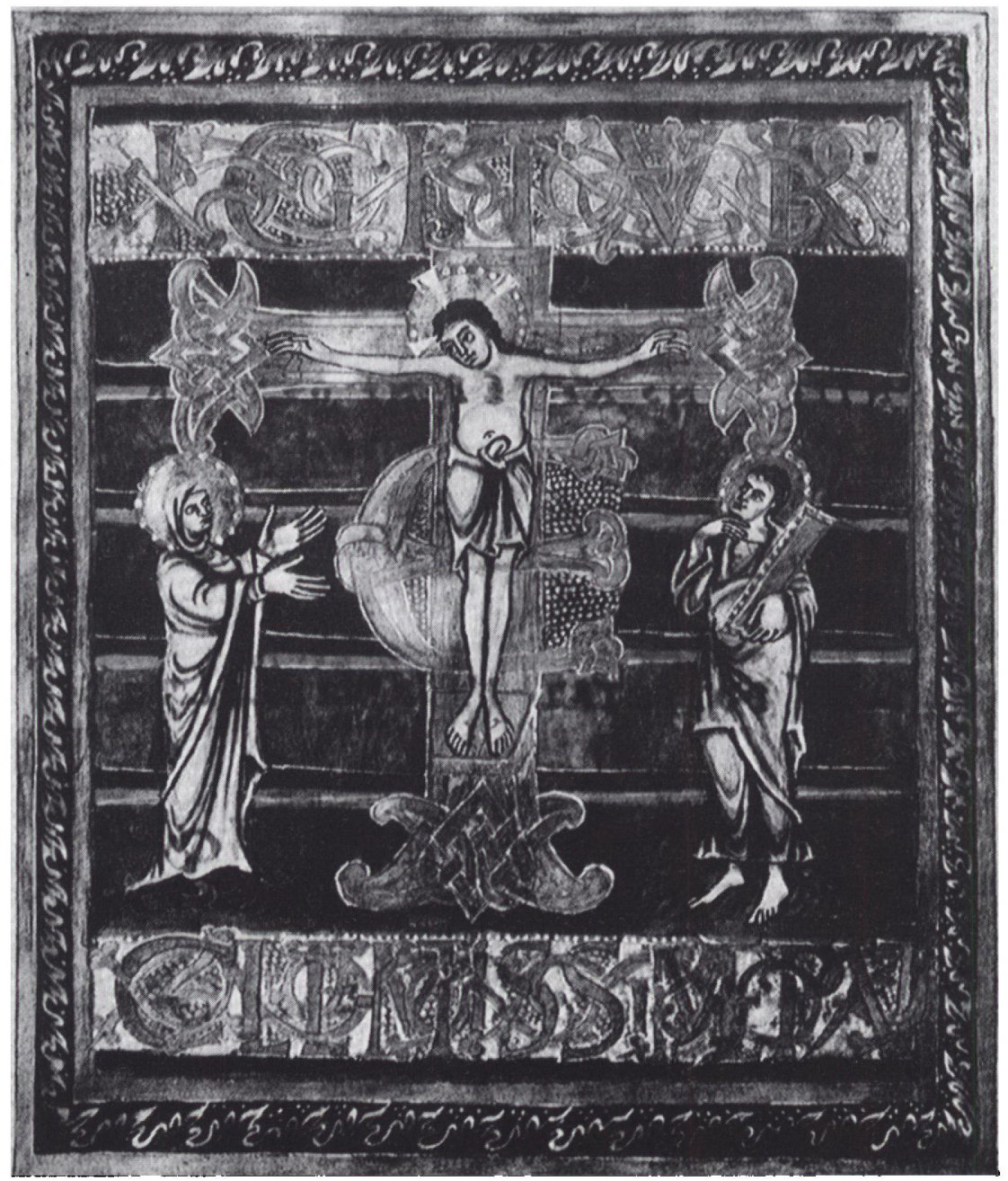

Ill. 14: Pd Gundbaldsakramentariet har Johannes en glorie besat med cirkler (perler?). Mon ikke hukommelsen har svigtet den gamle bronzestøber, da han skulle klargere støbepladen til Romskrinet (III. 13). Gengivet efter Elbern III. 16.

\section{Sammenfatning}

Frøslevskrinet, og dermed de øvrige knopskrin, der hidtil har været betragtet som forholdsvis primitive arbejder fra 1100-årenes første halvdel med oprindelsessted i Nordtyskland, Norden eller England/Irland, må på baggrund af en række stiltræk, der rækker længere tilbage $i$ tiden, nok snarere gives en tidligere 
datering. Skrinenes primitivitet må derfor ikke - som førhen - tages som udtryk for produktionsstedets tekniske og kunstneriske stade, men for arbejdets alder. En datering til 1000-årenes første halvdel synes ikke urimelig. Det avancerede farvevalg, der kendetegner knopskrinene, er typisk for det ottonske rige i sidste del af 900 -årene og frem til midten af 1000-tallet.

I denne periode er området kendt for sine metalstøberier, igangsat under biskop Bernward, der forstod sig på både kunsthåndværk og støbeteknik, og som var gejstligt overhoved for Hildesheim stift fra 993 til 1022. Disse traditioner blev senere udviklet videre under biskop Hezilo (1054-1079).

Fra dette område - dog med enkelte paralleller i Trier, Metz og Lindau kan der fra slutningen af 900 -årene og begyndelsen af 1000-årene påvises en række værker, der har så store lighedspunkter med knopskrinene, hvad angår teknik og motivvalg, at de må betegnes som forbilleder for disse.

De påviste forbilleder er:

Lindau evangeliaret

8.årh. slut/tidl. 9.årh.

Lothar d. 2. sarkofag, Walbek

964-1000

Eldste Mathildekors, Essen

974-982

Epikopbog fra Trier

964-1000

Yngste Mathildekors, Essen

0.1000

Bernward-krucifikset fra Ringelheim

0.1000

Korsfæstelsestavle Köln

0.1000

Ilfeld evangeliaret, Göttingen

0.1000

Adalberotavlen fra Metz, Paris

0.1005

Bernward-krucifikset fra Hildesheim 1007-1008

Hildesheim domkirkes gyldne madonna

1010

St. Mikaelskirken, Hildesheim

Gundbald-sakramentariet, Hildesheim

1014

Bronzedøren fra St. Mikaelskirken, Hildesheim

1015

Kostbares Bernward-evangeliar, Hildesheim

Biskop Bernwards sarkofag, Hildesheim

1022

Echternach-evangeliar, Nürnberg

St. Mikaelskirken, Hildesheim - arkaderne e.1046

Abbedisse Theophanu's bog, Essen

0.1050

Goslar Evangeliebogen

0.1051

Forbillederne for skrinenes motiver skal søges flere steder: på bronzedøren i St. Mikaelskirken i Hildesheim fra omkring 1015, i Kristusfremstillingerne i det ottonske område fra omkring 1000-1015 og i Echternach-evangeliaret fra 
omkring 1030. En snævrere og noget tidligere datering af skrinenes produktionstid til perioden 1015-60 forekommer derfor naturlig. ${ }^{20}$

Inspirationen bag Frøslevskrinet og de øvrige skrin må endvidere søges blandt benediktinermunkene. Forbillederne stammer $i$ høj grad fra benediktinerklostre, klosteret i Walbek, benediktinerklosteret knyttet til St. Mikaelskirken i Hildesheim, benediktinerklostrene i Wolfenbüttel og Rode.

Denne tradition og viden er dernæst opsamlet af benediktinermunken Rogers von Helmarshausen fra klostret af samme navn, der fra 0.1100 står som den store mester i faget. Når skrinene i dag genfindes i Italien og Tyskland må det være udtryk for gaverelationer mellem et sachsisk kloster og/eller en stiftsledelse og moderklosteret i Monte Cassino, samt pavestolen i Rom.

Benediktineme var i perioden fra o. 1050 og frem i stærk ekspansion bl.a. mod nord til Danmark. I sidste halvdel af dette århundrede blev de første benediktinerklostre oprettet herhjemme: Slesvig o. 1050, Lund før 1089 og Odense 1095. Der har derfor været behov for transportable altre, så den nye lære kunne forkyndes vidt omkring, i et Norden hvor kirkebygninger nærmere var undtagelse end regel. Det er måske også i dette lys man skal se Frøslevskrinet, trods dets uheldige endeligt i mosen.

\section{LITTERATUR}

Arenhövel, W.: Der Heziloradleuchter im Dom zu Hildesheim. Beitrăge zur Hildesheimer Kunst des 11. Jahrhunderts unter besonderer Berücksichtigung der Ornamentik. Berlin 1975.

Braun, J.: Eine Portatile im Nationalmuseum zu Kopenhagen. Zeitschrift für Christliche Kunst, 1910 , nr.8, sp. 249-254.

Buchreitz, G.: Anmeldelse af P.Svensson: Frøslevskrinet. Sønderjyske Arbøger 1982, 198-203.

Buddensieg, T.: Zur Ottonischen Buchmalerei und Elfenbeinskulptur in Sachsen. Studien zur Buchmalerei und Goldschmiedekunst des Mittekalters. Festschrift für Karl Herman Usener zum 60. Geburtstag am 19. August 1965. Marburg a.d. Lahn 1967.

Christiansen, Tage E.: Anmeldelse af P.Svensson: Frøslevskrinet, i: Fortid og Nutid, bd. XXX, hefte 3, 1983, 241-244.

Elbern, V.H. \& Reuther, H.: Der Hildesheimer Domschatz. Hildesheim 1969.

Falke, O.von \& Frauberger,H.: Deutsche Schmelzarbeiten des Mittelalters. Frankfurt a. M. 1904.

Grodecki, L. et. al.: Die Zeit der Ottonen und Salier.München 1973.

Hackenbroch, Y: Italienische Emails des frühen Mittelalters. Basel 1939.

Jantzen, H.: Ottonische Kunst. München 1947 (1990-udgave).

Kahsnitz, R. (red.): Das goldene Evangelienbuch von Echternach. Frankfurt a.M. 1982.

Liebgott, N.-K.: Middelalderens emaljekunst. Nationalmuseet. København 1985.

Lindahl, F.: Dagmarkorset, Orø- og Roskildekorset. Nationalmuseet. København 1980.

Nørlund, P.: An early group of Enammelled Reliquaries. Acta Archaeologica, 1933, vol.IV, 1-32.

Ronig, F.J.: Codex Egbern. Das Perikopenbuch des Erzbischofs Egbert von Trier (977-993). Trier 1977.

Springer, P.: Kreuzfüsse. Ikonographie und Typologi eines hochmittelalterlichen Gerätes. Berlin 1981.

Svensson, P.: Frøslevskrinet. Padborg 1981. 
Theophilus: On divers arts. (Theophilus og Rogers von Helmarshausen er en og samme person)

Kommenteret udgave ved J.G.Hawthorne og C.S.Smidt, New York 1973.

Wesenberg, R.: Bernwardinische Plastik. Berlin 1955.

\section{KATALOGER FRA UDSTILLINGER}

Rhein und Maas. Kunst und Kultur. Köln 1973.

Der Welfenschatz im Berliner Kunstgewerbemuseum. Berlin 1973.

Monumenta Annonis. Köln und Siegburg. Weltbild und Kunst im hohen Mittelalter. Köln 1975.

Lenger, A.: Ornamenta Ecclesia. Kunst und Künstler der Romanik. 1985.

1. De 10 skrin fordeler sig således:

Frøslevskrinet: Nationalmuseet i København.

Welferskrinet: Kunstgewerbemuseum i Berlin.

Hildesheim-skrinet: Landesmuseum i Hannover.

Rom-skrinet: Palazzo Venezia i Rom.

Lucca-skrinet: San Fredianokirken i Lucca.

Monte Cassino-skrinet: Klosteret i Monte Cassino.

London-skrinet: British Museum i London.

New York-skrinet: Metropolitan Museum of Art, New York.

Leningrad-skrinet: Cleveland Museum of Art, Cleveland.

Det tiende skrin, der indtil 2. Verdenskrig befandt sig i Berlin, forsvandt sporlast i 1945. Det var sandsynligvis et knopskrin, der kom fra Halle-området.

2. Nørlund 1933, 24.

3. von Falke 1904.

4. Artiklens hovedidé baserer sig på cand. phil. Hans Ole Matthiesens opgave om Frøslevskrinet afleveret til afd. for middelalderarkæologi ved Árhus Universitet sommeren 1990.

Cand. mag. Jørgen Smidt-Jensen har været med i den metodiske og sproglige omarbejdelse fra opgave til artikel.

Mag. art. Erik Levin Nielsen, Viborg Stiftsmuseum har igennem hele forløbet været en uvurderlig stor kilde til inspiration og nytænkning. Poul Svensson, Frøslev takkes for beredvilligt og uden begrænsning at have udlånt billedmaterialet fra bogen "Frøslevskrinet « (1981) til brug for denne afhandling. En del andringer skyldes endelig samarbejdet med Sønderjyske Årbøgers redaktion.

5. P. Springer, 1981, 99-101, Buchreitz 1982, 201.

6. Nørlund 1933, 17.

7. samme, 17.

8. samme, 9.

9. Christiansen 1982, 243.

10. Katalog Rhein-Maas, $261 \mathrm{ff}$.

11. Dateringen af de danske gyldne altre må formodentlig tages op til en fornyet revision, se note 20.

12. N.K. Liebgott, 1985, 14 eller F. Lindahl, 1980.

13. Hackenbroch, 1939,66 .

14. Buchreitz, 1982.

15. Under denne betegnelse er det første gang indfort i Welfersamlingens kataloger.

16. Jantzen, 1947, 114f - her i oversættelse af HOM.

17. Udover de 6 nævnte motivemner er der to andre motiver, nemlig de specielle baser og kapitæler samt sol og mảnemotivet, der ogsả genfindes indenfor det ottonske omrảde: Med impulser fra Corvey-klosteret genfindes de hornede baser og kapitaler $i$ et skrift fra benediktinerklosteret Rode, dateret 1000-1020 samt pả abedisse Theophanu's bog fra før 1056.

Sol og liggende mảne ses pả ærkebiskop Egbert af Triers Epikopenbog (Egbert var biskop her 977- 
993), på den hellige Heriberts kam fra Metz (dat. slutningen af 10. årh.), på korsfæstelsestavlen fra Köln (dat. 1000).

18. Rhein und Maas, 181.

19. Nørlund, 1933, 24. I ovrigt kendes teknikken fra abbedisse Theophanu's gyldne bogbind, udfærdiget for 1056, samt på bagsiden af Gundbald-evangeliaret fra 1014. Rogers von Helmershausen har altså her overtaget og perfektioneret en teknik, der allerede var kendt.

20. En nydatering efter den dendrokronologiske metode har ændret dateringen af det gyldne alter fra Lisbjerg, og er omtalt i JyllandsPosten 25. februar 1993.

Alteret er således ikke fra 1100-tallets slutning, men fra 1130-35. Da denne viden er så ny, og endnu upubliceret i faglitteraturen, er dateringen af de danske gyldne altre ikke ændret i denne artikel, jvfr. note 11 . 
